\title{
HEALTH LOCUS OF CONTROL PASIEN GAGAL GINJAL TERMINAL YANG MENJALANI HEMODIALISIS
}

\author{
Gusti Ayu Ary Antari ${ }^{1}$ \\ ${ }^{1}$ Program Studi Sarjana Keperawatan dan Profesi Ners Fakultas Kedokteran Universitas Udayana \\ Alamat korespondensi: aryantari@unud.ac.id
}

\begin{abstract}
Abstrak
Pasien gagal ginjal terminal yang menjalani hemodialisis rutin harus melakukan berbagai manajemen penyakit termasuk hemodialisis jangka panjang. Keyakinan (belief) diketahui dapat mengendalikan kesehatan pasien. Health locus of control menjadi sebuah konsep mengenai keyakinan yang dimiliki oleh pasien terkait kendali dalam status kesehatannya. Penelitian ini bertujuan untuk mengetahui gambaran health locus of control pasien yang menjalani hemodialisis. Desain penelitian ini adalah cross-sectional. Sebanyak 100 pasien hemodialisis yang telah mengisi multidimensional health locus of control scale dilibatkan dalam penelitian ini. Pengambilan data dilakukan di Ruang Hemodialisis RSD Mangusada dan RSUD Wangaya selama Bulan Juli-Agustus 2019. Hasil penelitian menujukkan bahwa rata-rata skor internal health locus of control lebih tinggi daripada chance maupun powerful others yaitu berturut-turut 29,35; 22,45; dan 27,95. Temuan ini mengindikasikan bahwa responden cenderung memiliki keyakinan akan diri sendiri (internal) yang lebih memiliki kendali atas kondisi kesehatannya dibandingkan orang lain, dokter maupun chance. Hasil tersebut berperan sebagai informasi penting mengenai health control belief yang dimiliki oleh pasien hemodialisis.
\end{abstract}

Kata kunci: Health locus of control, hemodialisis, gagal ginjal terminal

\begin{abstract}
Patient with kidney failure who are undergoing hemodialysis routine needs to carry out various disease management including long-term hemodialysis. Beliefs are known to control patient health. Health locus of control becomes a concept regarding the patient's belief and has control in their health status. This study aimed to identify a health locus of control in a hemodialysis patient. This study used a crosssectional design. One hundred hemodialysis patients completed the multidimensional health locus of control scale. Data were collected in the Hemodialysis Room at RSD Mangusada and RSUD Wangaya during July-August 2019. The results showed that the mean internal health locus of control was higher than chance and powerful others, namely 29.35; 22.45; and 27.95. The respondents in this study indicate that they believed themselves exerted more control over their health than other people, doctors, and chance. These results serve as important information regarding the health control beliefs of hemodialysis patients.
\end{abstract}

Keywords: Health locus of control, hemodialysis, kidney failure

\section{PENDAHULUAN}

Gagal Ginjal Terminal (GGT) merupakan penyakit ginjal kronis stadium lima yang bersifat irreversible dan menjadi penyebab krisis kesehatan global. GGT menjadi salah satu konstributor penting terhadap tingginya morbiditas dan mortalitas akibat penyakit tidak menular. Selain tingginya beban penyakit, GGT juga meningkatkan beban biaya perawatan terutama karena pasien harus menjalani terapi pengganti fungsi ginjal untuk mempertahankan kelangsungan hidupnya. Data yang ada saat ini menunjukkan bahwa jumlah pasien dengan terapi pengganti fungsi ginjal mencapai 2,5 juta dan jumlah tersebut diestimasi akan meningkat hingga 5,4 juta di tahun 2030 (Bikbov et al., 2020; Fan, Kong, Shi, \& Cheng, 2016; National Kidney Foundation, 2015). 
Secara umum, pasien GGT cenderung memilih dialisis jangka panjang sebagai terapi utama untuk meminimalkan risiko yang mungkin timbul akibat transplantasi. Hemodialisis dilaporkan menjadi pilihan utama pasien dibandingkan dialisis peritoneal (US Renal Data System, 2019; Antari, Sukmarini, \& Adam, 2019). Perawatan pasien GGT tidak hanya menitikberatkan pada hemodialisis rutin, namun terdapat aspek perawatan yang lainnya seperti pembatasan cairan, pengaturan diet dan pengobatan. Pasien harus melakukan berbagai perubahan gaya hidup untuk mendukung efek terapeutik dari hemodialisis dan meningkatkan kualitas hidup (Murali Id et al., 2019).

Studi yang ada sebelumnya melaporkan bahwa keyakinan (belief) dapat mengendalikan kesehatan pasien. Pada pasien dengan penyakit kronis seperti GGT, untuk mencapai perubahan perilaku kesehatan dan mencapai kepatuhan pasien terhadap pengobatan sangat penting untuk mempelajari keyakinan yang dimiliki (Aliha, 2015). Health Locus of Control (HLC) merupakan keyakinan yang dimiliki oleh pasien mengenai kontrol akan status kesehatannya. HLC menjadi sebuah konsep dimana individu menempatkan outcomes kesehatannya dalam kontrol oleh perilakunya sendirinya (internal HLC) atau dalam kontrol oleh orang lain (chance HLC dan powerful others HLC). Studi yang ada melaporkan HLC dapat meningkatkan kepatuhan pasien dalam melakukan manajemen penyakit dan meningkatkan kualitas hidup (Wallston et al., 1978; Griva, Jayasena, Davenport, Harrison, \& Newman, 2009; Theofilou, 2012).

Penelitian terkait HLC pada pasien GGT yang menjalani hemodialisis masih terbatas. Terdapat studi yang melaporkan bahwa pasien hemodialisis dapat memiliki rata-rata internal HLC yang lebih tinggi, namun studi yang berbeda justru menemukan pasien cenderung memiliki eksternal HLC yang lebih tinggi, khususnya powerful others. Berdasarkan pemaparan tersebut, penelitian ini dilakukan dengan tujuan untuk memperoleh gambaran health locus of control pada pasien GGT yang menjadi hemodialisis rutin.

\section{METODE PENELITIAN}

Desain penelitian ini adalah cross-sectional. Populasi penelitian adalah pasien GGT yang menjalani hemodialisis rutin di Ruang Hemodialisis Rumah Sakit Daerah Mangusada dan Rumah Sakit Umum Daerah Wangaya Provinsi Bali. Teknik pengambilan sampel dilakukan secara consecutive sampling. Penelitian dilakukan pada bulan Juli hingga Agustus 2019.

Sampel penelitian ini adalah pasien GGT yang menjalani hemodialisis rutin dua kali seminggu, berusia diatas 18 tahun dan bersedia menjadi responden. Pasien dieksklusi jika memiliki hemodinamik yang tidak stabil dan tidak mampu mengisi kuesioner secara lengkap baik karena kendala Bahasa maupun gangguan kognitif. Jumlah sampel penelitian ini adalah 100 orang.

Alat ukur yang digunakan dalam penelitian ini terdiri dari kuesioner karakteristik responden dan Multidimensional Health Locus of Control (MHLC) scale form C. MHLC scale form $\mathrm{C}$ telah digunakan untuk mengukur keyakinan pasien mengenai kontrol terhadap status kesehatannya (kondisi spesifik). MHLC terdiri dari tiga subskala yaitu internal, chance dan 
powerful others. Pada MHLC scale form $\mathrm{C}$, powerful others terdiri dari dua subskala yaitu doctors dan other people. MHLC scale form $\mathrm{C}$ terdiri dari 18 pertanyaan (masing-masing enam pertanyaan untuk subskala internal dan chance sedangkan masing-masing tiga pertanyaan untuk subskala doctors dan other people) (Wallston; Stein; Smith, 1994).

Setiap pertanyaan memiliki enam poin skala Likert dengan rentang jawaban dari "sangat setuju" hingga "sangat tidak setuju". Rentang skor total untuk setiap subskala adalah 6-36. MHLC scale ini telah dinyatakan valid

\section{HASIL PENELITIAN}

Responden penelitian ini memiliki rata-rata usia 53,86 tahun $(\mathrm{SD}=12,12$ tahun). Jenis kelamin laki-laki sebanyak $65 \%$ sedangkan perempuan $35 \%$. Ratarata lama menjalani hemodialisis adalah 3,44 tahun ( $\mathrm{SD}=2,56$ tahun). Responden yang memiliki jadwal hemodialisis pagi sebanyak $48 \%$ dan reliabel, nilai Cronbach's alpha untuk setiap subskala adalah 0,7-0,8.

Prosedur pengumpulan data terdiri dari pengurusan ijin penelitian, penetapan kriteria inklusi dan eksklusi, penjelasan penelitian, informed consent dan pengambilan data menggunakan kuesioner. Penelitian telah lolos uji etik oleh Komite Etik Fakultas Kedokteran Universitas Udayana. Analisis data penelitian menggunakan program komputer dan mencakup analisis univariat untuk menggambarkan tendensi sentral dari variabel penelitian.

sedangkan sore sebanyak 52\%. Apabila ditinjau dari pekerjaannya, responden yang bekerja sebagai PNS sebanyak $2 \%$, pegawai swasta $7 \%$, wiraswasta $10 \%$, pensiunan $6 \%$ dan pekerjaan lainnya sebanyak $75 \%$.

Tabel 1.

Gambaran Health Locus of Control

\begin{tabular}{lccc}
\hline $\begin{array}{l}\text { Health Locus of } \\
\text { Control }\end{array}$ & Mean \pm SD & Min - Max & $\mathbf{9 5 \%}$ CI \\
\hline Internal & $29,35 \pm 3,006$ & $17-35$ & 28,$75 ; 29,95$ \\
\hline Chance & $22,45 \pm 5,837$ & $9-34$ & 21,$29 ; 23,61$ \\
\hline Powerful others & $27,95 \pm 3,135$ & $18-36$ & 27,$33 ; 28,57$ \\
- Doctors & $15,75 \pm 1,61$ & $11-18$ & 15,$43 ; 16,07$ \\
- Other & $12,20 \pm 2,74$ & $5-18$ & 11,$66 ; 12,74$ \\
$\quad$ people & & & \\
\hline
\end{tabular}

Berdasarkan tabel 1 diketahui bahwa rata-rata internal health locus of control adalah 29,35 (SD = 3,006), chance health locus of control adalah $22,45(\mathrm{SD}=5,837)$ dan powerful others health locus of control adalah 27,95 $(\mathrm{SD}=3,135)$. Rata-rata subskala doctors adalah 15,75 $(\mathrm{SD}=1,61)$ sedangkan other people adalah 12,20 $(\mathrm{SD}=2,74)$. 


\section{PEMBAHASAN}

Berdasarkan temuan penelitian diketahui bahwa responden penelitian memiliki rata-rata skor HLC internal yang lebih tinggi dibandingkan HLC eksternal. Sementara diantara HLC eksternal, powerful others memiliki ratarata yang lebih tinggi. Sebuah studi yang dilakukan oleh Theofilou (2012), menemukan skor yang lebih tinggi pada domain internal dan chance HLC. Namun, pada studi yang dilakukan oleh Fan et al. (2016) dan Aliha (2015) menemukan bahwa poweful others HLC memiliki skor yang paling tinggi.

Pada responden penelitian, kebanyakan pasien merasa memiliki tanggung jawab langsung akan kondisi dirinya. Pasien merasa dirinya memiliki kendali utama terkait kesehatannya, misalnya mengenai kepatuhan dalam pengaturan cairan, diet, maupun penggunaan obat-obatan. Oleh karenanya, dalam beberapa studi dijelaskan bahwa pasien dengan internal HLC yang lebih tinggi seringkali dikaitkan dengan respon emosional yang lebih rendah, pemahaman penyakit dan kualitas hidup yang lebih baik (Theofilou, 2012).

Pada kondisi sakit, pasien GGT dapat mengalami berbagai perubahan kondisi akibat penyakit seperti kehilangan kepercayaan diri, kondisi yang tidak pasti, kehilangan pekerjaan dan sebagainya yang menyebabkan pasien merasa bahwa aspek ekternal lebih bertanggungjawab akan kondisi kesehatannya. Beberapa studi juga menemukan perbedaan budaya dapat mempengaruhi HLC. Oleh karenanya, pada studi berikutnya dapat dipertimbangkan aspek budaya yang dimiliki oleh responden dalam membahas HLC.
Pasien GGT yang menjalani hemodialisis rutin dilaporkan memiliki kecenderungan kontrol personal (HLC internal) dalam mengelola kondisi kesehatannya. Hal ini mungkin karena pasien cenderung menggunakan mekanisme koping yang berfokus pada masalah sehingga pasien berupaya memiliki kendali penuh akan kondisi dirinya. Pasien merasa perlu memiliki kemampuan perawatan diri yang sesuai dengan kondisi penyakit dan perubahan gaya hidup yang sesuai (Mahmoud \& Abdelaziz, 2015).

Hasil penelitian menunjukkan bahwa rata-rata skor subskala dokter lebih tinggi daripada orang lain $(15,75$ berbanding 12,20). Hasil ini dapat mengindikasikan bahwa pasien GGT yang menjalani hemodialisis rutin cenderung meyakini bahwa status kesehatannya sangat dipengaruhi oleh dokter. Hal ini mungkin karena pasien merasa kesehatannya akan baik-baik saja jika rutin mengunjungi dokter. Selain itu, peresepan hemodialisis dan pengobatan juga tergantung pada keputusan dokter (Mahmoud \& Abdelaziz, 2015).

Pada kondisi eksternal HLC yang lebih dominan, tenaga kesehatan perlu merancang program edukasi untuk membantu pasien dalam membentuk keyakinan personal terkait kesehatannya. Pasien perlu memiliki HLC internal untuk mendukung manajemen penyakitnya.

\section{SIMPULAN DAN SARAN}

Hasil penelitian ini menunjukkan bahwa rata-rata skor internal health locus of control lebih tinggi daripada chance maupun powerful others yaitu berturut-turut 29,35; 22,45; dan 27,95. Hasil tersebut berperan sebagai informasi penting mengenai health control belief yang dimiliki oleh pasien hemodialisis. Selanjutnya hasil ini dapat 
dikembangkan dalam penelitian terkait peranan health locus of control dalam meningkatkan manajemen penyakit pasien hemodialisis.

\section{DAFTAR PUSTAKA}

Aliha, J. M. (2015). Client-Centered Nursing Care The Relationship between Quality of Life and Health Locus of Control Beliefs in Hemodialysis Patients (Vol. 1).

Antari, G. A. A., Sukmarini, L., \& Adam, M. (2019). Associated factors of post-hemodialysis recovery time in kidney failure patients. Enfermeria Clinica, 29, 247-251. https://doi.org/10.1016/j.enfcli.2019 .04 .139

Bikbov, B., Purcell, C. A., Levey, A. S., Smith, M., Abdoli, A., Abebe, M., ... Chronic Kidney Disease Collaboration, G. (2020). Global, regional, and national burden of chronic kidney disease, 1990Ã đâ, ᄀâ€œ2017: a systematic analysis for the Global Burden of Disease Study 2017. The Lancet, 395, 709-733.

https://doi.org/10.1016/S01406736(20)30045-3

Fan, J. L., Kong, Y., Shi, S. H., \& Cheng, Y. H. (2016). Positive correlations between the health locus of control and selfmanagement behaviors in hemodialysis patients in Xiamen. International Journal of Nursing Sciences, 3(1), 96-101. https://doi.org/10.1016/j.ijnss.2016. 02.002

Griva, K., Jayasena, D., Davenport, A., Harrison, M., \& Newman, S. P. (2009). Illness and treatment cognitions and health related quality of life in end stage renal disease. British Journal of Health

Psychology, 14(1), 17-34.

https://doi.org/10.1348/135910708 X292355

Mahmoud, S., \& Abdelaziz, N. A. (2015). Association between Health Locus of Control, Self-care and Self-efficacy in Patients with End Stage Renal Disease Undergoing Hemodialysis. In Life Science Journal (Vol. 12). Retrieved from http://www.lifesciencesite.com58

Murali Id, K. M., Mullan, J., Roodenrys, S., Hassan, H. C., Lambert Id, K., \& Lonergan Id, M. (2019). Strategies to improve dietary, fluid, dialysis or medication adherence in patients with end stage kidney disease on dialysis: A systematic review and meta-analysis of randomized intervention trials. https://doi.org/10.1371/journal.pone .0211479

National Kidney Foundation. (2015). Global Facts: About Kidney Disease . Retrieved August 8, 2020, from https://www.kidney.org/kidneydise ase/global-facts-about-kidneydisease

Theofilou, P. (2012). Quality of life and mental health in hemodialysis and peritoneal dialysis patients: The role of health beliefs. International Urology and Nephrology, 44(1), 245-253. https://doi.org/10.1007/s11255-0119975-0

US Renal Data System. (2019). Annual data report: Epidemiology of kidney disease in the United States executive summary.

Wallston; Stein ; Smith. (1994). Form C of the MHLC Scales: A conditionspecific measure of locus of control,. Journal of Personality Assessment, 63(3), 534-553. 
https://doi.org/https://doi.org/10.12 07/s15327752jpa6303_10

Wallston, K. A., Ph, D., Wallston, B. S., Ph, D., Devellis, R., \& Ph, D.

(1978). Development of the Multidimensional Health Locus of Control (MHLC) scales. Health Education Monographs Spring, 6(2), 160-170. 